\title{
Perspectives
}

\section{"Canadian Culture," Cultural Difference, and ESL Pedagogy: A Response to Robert Courchêne and Virginia Sauvé}

Lisa Taylor

Defense is by definition conservative: the greatest challenge to the political left in the Canada of the 1980s and 1990s has been to continue exploring progressive directions openly and creatively in the face of a neo-right onslaught that would keep us scurrying just to protect the status quo, couching our arguments in the language of national traditions, institutions, and values. A discussion of "Canadian culture" - what it is, what it has to do with learning ESL, and how to teach it-might best begin, then, with the recognition that the current climate of siege has an impact on how we are approaching the very idea of culture. As Canadians voice their concern for the loss of any cultural protection from free trade; as federalists argue for national unity; as so many rally to save the CBC: Canadians are articulating notions of Canadian culture framed by their goals of conservation.

Some of these notions are suggested in Walcott's (1996) review of the art exhibition, The Oh! Canada Project, mounted only months after the nation was shaken by the Quebec referendum. Listening to passing conversation in the main space of the exhibition, a Group of Seven retrospective, Walcott remarked that he felt himself to be at a wake for an imagined collective history, a nostalgic mourning for the lost "national unity based on [a modernist] idea of sameness" of a predominant Anglo-Saxon settler society. I too had been struck by different concepts of culture circulating in this exhibition: the Group of Seven paintings suggesting founding fathers, selective history, and an accumulated canon; the "community-based" installations of ethnic minority artists' work, a participative "graffiti wall" and a speakers' corner invoking a sense of culture as an effect of human interaction and innovation, as incomplete and dependent on the reader for meaning.

In this example I am trying to highlight that the very definitions of culture that we work with carry political agendas that position individuals differently in terms of legitimacy and belonging. If you consider culture as involving a learnable ${ }^{1}$ body of knowledge, then the task of teaching it would lie in deciding which bodies represent Canadian culture, discovering their unique knowledges of what makes them Canadian, and teaching it to those who do not yet know it. It becomes difficult in this framework, however, to talk 
about perceptions of self and others in relations of belonging and exclusion, about how meaning is established, and what it makes impossible for different bodies.

\section{"Cultural Knowledge" and "Cultural Relations"}

These questions of how we as ESL pedagogues might think about culture, cultural difference, and national belonging, especially in relation to our goals of "empowerment" and facilitation, were raised in an intriguing conversation between Robert Courchêne and Virginia Sauvé published in the Spring 1996 issue of the TESL Canada Journal. In appreciation of the many excellent points and suggestions made in this dialogue, I hope to add my reflections to the discussion.

Responding to and expanding on Courchêne's article on how Canadian culture might be taught as a subject in ESL curriculum, Sauvé (1996) states, "Culture is not about content. It is about the making and remaking of relationships in our society" (p. 23). She discusses some of the pitfalls in trying to conceive of culture as content: the impossibility of representing the specificity of culture according to region, age, gender, ethnicity, class, race, rural versus urban locale, and work, to name some of the variables at play (p. 18), and the unavoidable flattening out of the discursive convergence of the psychic and the social at the heart of cultural practices, an erasure that tends to occur especially when cultural content is taught in the delivery mode.

Courchêne argues in response to Sauve that he sees culture as consisting of both cultural knowledge and cultural behavior: "when [cultural knowledge] become internalized, it becomes a force that shapes and guides the lives of the members of that culture, a force that is frequently exerted on the subconscious level ... Although cultural knowledge may ultimately not be as important as cultural actions and cultural relationships, it remains an important aspect of any culture" (pp. 24-25, italics added).

\section{Cultural Diversity and Cultural Difference}

On revisiting the article, my impression was that Courchêne's argument in his insistence on the value, however qualified, of a vision of culture as knowledge that can be taught, traced a crosshatched path along the tension between two distinct approaches to the question of culture. Following the postcolonial theorist Bhabha (1994), I will call them the "cultural diversity" approach and the "cultural difference" approach. In the first, culture is cast as an "epistemological object ... a [theoretical] category of comparative ethics, aesthetics or ethnology" (p. 34) in which different cultures can be examined, described, compared, analyzed, or organized according to their contents. Whether the relations between different cultures are understood as being outside power relations or within a hierarchy of power, little attention is paid to the preliminary process through which these contents were framed. 
In contrast, questions of framing and representation are central to a cultural difference approach to the question of learning and teaching culture. As I understand it, this is a very different pedagogical orientation: it launches a project of investigating how certain formulations of cultures accrue categorical status, come to function as authoritative frames of reference, and incite identification. If the notion of cultural diversity inspires attempts to know different cultures, the notion of cultural difference asks how "cultures" come to be "knowable and known, and what relations they establish between knowers" (Bhabha, 1995, pp. 206-207).

There are reasons to be cautious of a cultural diversity approach. As Courchêne explains, its pedagogical approach of encyclopedic listmaking reinforces power relations of exclusion and normalization, and attempts to fix and totalize something that is dynamic and disrespectful of boundaries. There is also a danger that the fascination with cataloguing differences can end up reinforcing both the impression of profound, stable differences between groups, and the affixing of this onto the bodies of others such that it comes to represent their identity. This is the risk of activities such as having student teachers interview newly arrived immigrants of different cultures and fill out "culturegrams" on them (an example cited by Courchêne). Even when relations of marginalization between these immigrant cultures and the dominant group (to which most student teachers belong) are named, even with the best of intentions the experience of gaining knowledge about these other cultures can still end up reinforcing binaries of difference versus "normalcy."

Most important in my view is the recognition implicit in the notion of cultural difference that culture is always about belonging, identification, and legitimacy; about strategic, shifting boundaries that constitute an " $\mathrm{I}$," a "We," and a "They."

This means that my most important goal as an ESL pedagogue in relation to my students' cultural learning is to contribute to their sense of legitimacy and membership in this dynamic society. This means paying attention to how everything I say about culture and cultural difference, and specifically Canadian culture, "constitutes, even as it mobilizes and shuts out, imaginary communities, identity investments and [regulatory] practices" (Britzman, 1995, p. 239). Who are the "I," "we," and "they" that our pedagogy and course material invoke in discussion of popular and canonized culture, of biculturalism, and of multiculturalism? To which bodies are we referring in exercises designed to introduce students to the cultural know-how needed to live in Canada?

For these reasons I strongly agree with Sauve in insisting that bodies of knowledge and knowledge of bodies not be artificially separated: that is, that in trying to understand and facilitate our students' acculturation we should not follow a structural or economic model of stable, coherent subjects acquir- 
ing quantities of universal cultural knowledge or "capital." If, as I would argue, cultural knowledge is always about value, authenticity, and morality, about representational struggles, collective remembering, and the formation of identities and subjectivities, then different bodies will be implicated and positioned differently in the knowledge they learn and the relations they negotiate. ${ }^{3}$ As Sauvé notes, working with our students and immigrant educators can help us better take into consideration the risks and hierarchies of credibility arrayed along axes of race, color, gender, class, legal status, nation of origin, accent, sexuality, and ability, among others. It is these complex power relations, configured differently in each situation, that our students negotiate with every foray into their new culture and society.

\section{An Expanded New Cultural Vision for an Expanded National Cultural Project}

One of the implications of this is that I would expand Courchene's first element in his intriguing "new cultural vision"; that is, an historical perspective on how this society and its laws have developed as they have. Because all of us who are not of Aboriginal heritage are immigrants to Canada, I would broaden our vision of how we came to be here today to include the bigger global picture. For many of us, our ancestors came to escape religious persecution or oppressive social and economic conditions in Europe to a land that was empty (both physically and symbolically) to offer them a dream of innocent freedom and new beginnings founded on hard work. For some of us, our ancestors tried to come and were denied or allowed only under the most stringent conditions in response to the labor market. For others of us, our ancestors came to escape slavery or imperialism that had made their homelands unlivable. For still others, our relatives came after European expansionist imperialism imploded in the two World Wars. Others have come in the hope of finding a better life than was available in countries still suffering the aftermath of European imperialism (political turmoil and economic underdevelopment) in addition to the new onslaughts of corporate neocolonialism. And finally, some of us are still here despite 500 years of genocidal policies.

All these stories are part of our history as Canadians and need to be retold as part of our collective memory and cultural heritage. One exercise I have used as an ESL teacher is to ask my students to trace their paths-beginning with either themselves or grandparents if this is relevant-which have led them to this classroom today. I ask them to punctuate visually this path with four or five significant events or decisions. I do the same for my own life journey, and then attempt to assemble our various paths on the blackboard, making connections between them. I am never sure where the discussion will take us, but in the past it has touched on issues such as underdevelopment, the international status of English, the impact of European and 
American imperialism, the Cold War, ethnic wars, individual courage, and the strength of family ties. It is not an easy exercise, but it certainly demystifies my position as teacher: I once embarked on a what if? path that led to the class finding ourselves in, say, India learning Hindi from one of the students who in this scenario ended up as teacher.

This perspective shifts the focus in discussions of Canadian culture from hierarchies of authenticity and legitimacy (i.e., in which ethnic groups laid the foundations of our current society) to the project at hand engaging us all: forging a rich, diverse, and equitable society. In this sense I applaud the second element in Courchêne's new cultural vision, the common rights and freedoms (and, I would add, responsibilities), which found our loyalty and membership to this society. As Courchêne insightfully remarks, cultural membership in this sense is based less on common history or traditions than on personal and legal commitment, on participation, and sharing a common stake in this larger project. To be successful this project will need to be based on certain shared values, such as appreciation of diversity, respect for difference, commitment to equity and social justice, and responsibility to the social collective.

Finally, I would add to the four elements (a reflection of Canada's past, a vision of common rights and freedoms, a recognition of all Canadian voices, and inclusive of some common traditions and symbols) named by Courchêne a fifth: a vision of what we are becoming. Inspired by the view of culture - as innovative, syncretic, and dialogic-interactive - suggested by the community-based installations of the Oh! Canada exhibition, I strongly believe we need to include in the ESL curriculum opportunities to engage with emerging cultural production. Films such as Masala, Rude, Soul Survivor, and Double Happiness, ${ }^{4}$ plays such Andrew Moody's Riot or Guillermo Verdecchia's Fronteras Americanas, work by authors Dionne Brand, Joy Kogawa, Paul Yee, Himani Bannerji, Lee Maracle, Austin Clark, Beth Brant, and Taien $\mathrm{Ng}$ all explore cultural expressions and difference in creative ways that dislodge stereotypes that package ethnicity into concentric, unequal multicultures. In fact, the experiences of cultural hybridity and compromise portrayed in this work are probably easier for students to identify with than decontextualized attempts to instruct them in dominant social codes; at the same time, the stories invite discussion of these codes from students' subject positions and interests.

Developing curriculum, pedagogy, learning activities, and events for all students and teachers of the school around the topic of culture-culture as a dynamic expression of ongoing, resistant re/creativity-opens up positive venues through which to disrupt negative or commodifying, nostalgic images of cultural essence. It opens up spaces of relationality and communication that, while never outside relations of power, allow some latitude for ESL 
students to negotiate the gaps between mass-mediated images and their daily lived realities.

\section{Teacher Preparation: Notes of Caution}

I wholeheartedly agree that preparing teachers to teach this approach to the cultures of Canada will be a major project, and Courchêne and Sauvé make excellent suggestions to this end. Certainly the four elements of Courchene's new cultural vision (and a fifth that I have added) will need to be included in a preservice course on multicultural history, citizenship, and antiracism. Toward these goals Orr and Finney's (1995) program stands out as one that encourages sustained interaction with "cultural others" as authoritative subjects, not as objects of study or "inclusion." Tremendous attention should also be paid in these courses to student resistance: antiracist, antihomophobia, and AIDS awareness educators have learned that a change in consciousness often involves not simply the acquisition of new knowledge, but the rearrangement of how one views oneself, one's standards of normalcy, and all that one "cannot bear to know" (Britzman, 1991, 1995; Britzman, Santiago-Valles, Jiménez-Muñoz, \& Lamash, 1993; Patton, 1990). Many student teachers may find the experience of being "decentered," of reorganizing their vision of Canada and Canadian culture away from a model focused on "two founding cultures" and postwar European immigration very unsettling. However, extensive use of journals and small-group discussion can provide low-pressure forums in which these challenges might be worked through while holding on to the vision that, while we benefit unequally from systems of marginalization, we can all play a role in changing them.

My thanks to Robert Courchêne and Virginia Sauvé, as well as the TESL Canada Journal for opening this extremely fruitful and long-overdue discussion.

\section{The Author}

Lisa Taylor is a doctoral candidate in the Ontario Institute for Studies in Education, University of Toronto (OISE-UT). She is an ESL teacher with the Toronto Board of Education.

\section{Notes}

${ }^{1}$ I agree with Sauve that the fact that culture is to a certain degree learnable does not necessarily imply that it is directly teachable.

${ }^{2}$ I use "scare quotes" here to signal that I do not wish to use this term uncritically, collapsing complex relations of material and representational marginalization in its implied metaphor of "helping someone become more powerful"; at the same time, in recognizing that power is fluid and that we all participate in it, I want to hold on to the idea that we as educators are working toward more equitable social relations of power.

${ }^{3}$ I have argued this elsewhere (Taylor, 1997). 
${ }^{4}$ All these Canadian productions are available on video. The directors are, respectively: Srinivas Krishna, Clement Virgo, Stephen Williams, and Mina Shum. Fronteras Americanas has been published as a play by Coach House Press and is also available as a video through V-Tape in Toronto.

\section{References}

Bhabha, H. (1990 Interview with Homi Bhabha: The third space. In J. Rutherford (Ed.), Identity, community, culture, difference. London: Lawrence \& Wishart.

Bhabha, H. (1994). The location of culture. New York: Routledge.

Bhabha, H. (1995). Cultural diversity and cultural differences. In B. Ashcroft, G. Griffiths, \& H. Tiffin (Eds.), The post-colonial studies readers (pp. 206-211). London: Routledge.

Britzman, D. (1991). The ordeal of knowledge: Rethinking the possibilities of multicultural education. Review of Education, 15, 123-135.

Britzman, D. (1995). Is there a queer pedagogy? Or, Stop reading straight. Educational Theory, 45. 151-165.

Britzman, D., Santiago-Valles, K., Jiménez-Munoz, G., \& Lamash, L. (1993). Practice makes practice: A critical study of learning to teach. New York: SUNY Press.

Courchêne, R. (1996). Teaching Canadian culture: Teacher preparation. TESL Canada Journal, 13(2), $1-16$.

Courchêne, R. (1996). Response to Virginia Sauvé. TESL Canada Journal, 13(2), 24-25.

Orr, J., \& Finney, S. (1995). Making cross-cultural education meaningful through face-to-face experiences. Journal of Professional Studies, 3(1), 29-38.

Patton, C. (1990). Inventing AIDS. New York: Routledge.

Sauvé, V. (1996). Working with the cultures of Canada in the ESL classroom: A response to Robert Courchêne. TESL Canada Journal, 13(2), 17-23.

Taylor, L. (1997). Contingent belonging: Race, culture and nation in ESL pedagogy. Unpublished master's thesis, OISE/UT.

Walcott, R. (1996). Lament for a nation: The racial geography of "The Oh! Canada Project." FUSE Magazine, 16(4), pp. 15-23. 